\title{
Different Associations of Animal Words in English and Chinese and the Relevant Translation Strategies
}

\author{
Fade Wang \\ Foreign Language College, Huaiyin Institute of Technology, 223001, Jiangsu, China \\ Minglan Zhang \\ Foreign Language College, Huaiyin Institute of Technology, 223001, Jiangsu, China
}

\begin{abstract}
There are a large number of phrases containing animal words both in English and Chinese. However, many associative meanings concerning animal words existing in English and Chinese cultures are different or even opposite due to historical and cultural differences. In order to translate relevant phrases correctly, translator should know the different associations of animal words in English and Chinese. This paper aims at pointing out associative differences of a large quantity of animal words in English and Chinese as well as dealing with translation of animal idioms and relevant phrases with domestication, foreignization, and domestication or foreignization plus explanation so as to reach dynamic equivalence of source language and target language in translation.
\end{abstract}

Index Terms - animal words, differences in association, domestication, foreignization

\section{INTRODUCTION}

Human beings have been acquainted with animals and animals' habits since the primitive times. During human beings' knowing and utilization of animals, animals are gradually integrated into human beings' cultural activities and play a great role in human beings' culture. We often consider animals like dogs, cats as our intimate friends in every corner of the world. That may explain the reason why human beings use relevant animal phrases to express their emotions, experiences and feelings and use animal idioms to explain complicated rules and phenomena vividly.

It is worldwide acknowledged that animal names, relative phrases have acquired many established associative meanings in various languages with the development of language, therefore animal names, relative phrases and idioms are attached great importance in every country with great significance in each language. However, Chinese and English nations are different in terms of geographic locations, histories, ecological surroundings, religious beliefs, customs, aesthetic values and the ways of thinking, which make people produce different associative meanings about same things. English and Chinese nations are abundant in idioms of animals' names while animal words in different countries acquire different associative meanings, which lead to misunderstanding of true meanings of animal idioms between English and Chinese culture. With increasing intercultural communication and globalization, having a good knowledge of correct associative meanings of animal words between English and Chinese culture becomes the first step toward excellent translations and a perfect translation of animal idioms between English and Chinese not only brings readers of target language a vivid cultural and exotic picture but also enriches the language of each country.

This paper is on associative differences and translation of animal words between Chinese and English culture, aiming at pointing out associative differences of a large quantity of animal names between Chinese and English culture as well as dealing with translation of animal idioms and relative phrases with domestication, foreignization, and domestication or foreignization plus explanation so as to reach dynamic equivalence of source language and target language.

\section{Associations of ANimal Words In ChINESE AND ENGLiSH}

\section{A. The Same Animal Words with Identical Meanings}

Although in the world there are remarkably different cultures and various nations as well as extremely various languages, people may endow some natural objects with corresponding or similar humanoid feelings, so they often share similar cultural connotations, aesthetic and moral values. As the common features of humanity are reflected in different cultures, it is bound that similar connotations of animal words exist indifferent languages. The following are some animal words with corresponding or similar implications in English and Chinese.

(1) "wolf": Wolf in Chinese and English cultures have the same meaning. It refers to somebody fierce, cruel or greedy, such as “as cruel as a wolf”(像狼一样凶残)

(2) "Sheep": Sheep in both Chinese and English cultures are analogous to someone who is meek and tender, such as 
“as gentle as a sheep”(温顺的像只绵羊)

(3) "Ass and donkey": Ass and donkey in Chinese and English languages have negative meanings which indicate that someone is stupid ,foolish and stubborn, such as “make an ass of oneself”(使自己出洋相), as stubborn as a donkey(非 常固执).

(4) "Monkey": Being naughty and lovely is the associative meaning both in Chinese and English, such as "monkey around"(胡闹).

(5) "Parrot": Parrot has the ability to imitate what people say, so people in china and English-speaking countries use this animal name as a metaphor to describe those who always imitate others' words, which makes people feel unpleasant. For example, “Don’t parrot my words"( 别模仿我的话).

(6) "Dove": No matter in Chinese mythology or in Biblical stories, dove is applied to symbolize peace and good fortune.

(7) "Snake": It is widely acknowledged that snake in Bible enticed Eva into breaking rules to eat apples in the tree in the paradise. Finally, Adam and Eva were expelled from the paradise by God because they didn't resist snake's temptation. "Snake" in Chinese culture also refers to sinister people. For example, “as evil as a snake" (像蛇一样邪恶)

(8) "Chameleon": Both in Chinese and English people and things which are remarkably changeful are described as chameleon(变色龙).

(9) "Bee": Bee possesses the same associative implication of being industrious and busy in both languages . For example, “as busy as a bee”(像蜜蜂一样忙碌).

\section{B. The Same Animal Words with Different Associative Meanings}

In English and Chinese, we often find that the same animal words have extremely different associative connotations in which case some animal words are commendatory in Chinese while derogatory in English or vice versa. It is different cultural backgrounds that make the same animal words endowed with different associations. The following examples are about the same animal words which are given different associative meanings.

(1) "Dragon": In Oxford Advanced Learner's Dictionary of Current English this imagined animal is described as afabulous creature which is like a crocodile or snake, often with wings and claws, able to breath out fire, often guarding a treasure, symbolizing a fierce person. In western mythology, dragon is a kind of monster spurting fire with a pair of wings and snake-like tail. It symbolizes being cruel and evil. In Bible, Satan is called the huge dragon. In contemporary English, if you use this word to describe a person, there is derogatory meaning in it. If you call a woman a dragon, you mean that she is cruel, fierce or unfriendly. However, we, Chinese people, call ourselves the descendants of dragon. In fact, in Chinese mythology, dragon is a deity animal which could produce clouds and rain. Chinese people all regard dragon as a symbol of good fortune and best wishes.

(2)“Bat”: The Chinese character “蝠” has the same pronunciation with “福”, so "bat" has the meaning of good luck in Chinese culture, while in English, bat makes people have the association of ugliness and sin. When referring to bat, western people think of it as vampire. The legend goes like that vampires drink the living's blood.

(3) "Owl": In Greek and Roman myth, owl often perches beside Athena-the Goddess of wisdom, therefore owl is a kind of bird symbolizing wisdom or brilliance. It is asked to solve conflicts among animals and is consulted in emergency. On the contrary, the image in Chinese culture is unfortunate. Chinese folk legends go like that if someone hears yelling of owl or an owl stands on somebody's tree, a member in his family would be doomed to die, or something inaspicious will befall this family, so people associate this animal with death and bad luck, considering it the sign of ill omen.

(4)"Whale": Whale is large in size with incredible amount of fat. Once captured, whale can bring abundant profits. Therefore, in English culture whale is dubbed as advantageous stuff or extraordinarily beautiful persons, such as "a whale of a chance”(极好的机会). In Chinese culture, people attach more importance to its great appetite instead of its value in use, so whale is usually used to refer to the stong who devour or prey upon the weak .

(5) "Cat": In Chinese the cultural connotation of cat is usually thought of as cuteness and relaxation. In western countries cat is the embodiment of demon and the patron saint of witches in middle ages. Especially, the black cat is the most disgustful in English culture.

(6)"Phoenix": According to Chinese legends, phoenix is the queen of birds, so the saying goes like all birds paying homage to the phoenix. Chinese people hold the opinion that the appearance of phoenix indicates the peace of the whole world. In Chinese culture, phoenix not only brings auspiciousness but also symbolizes the virtue of human beings. In ancient times phoenix was compared to people with holy virtue, such as “凤毛麟角” which refers to rare valuable things and people who are of exceptional talent or virtue. However, in English culture, it was said that phoenix lived in Arabic desert for five and six hundred years and built a nest that was carpeted with spice before its death. After singing a piece of bleak elegy, it stirred up fire with wings and burned itself into ash, finally, another new phoenix came into being. Therefore, English people endow the phoenix withthe implication of rebirth.

(7) "Magpie": In Chinese culture, magpie's chirping not only brings good messages but also indicates the foreboding of fine weather. However, magpie in English culture is referred to as chatterers, such as "she is a magpie of a woman" 


\section{(她是个饶舌的女人).}

(8)"Petrel": In Chinese culture, as brave bird Petrel has the confidence to overcome obstructions with perseverance. It is the symbol of brave warrior undauntedly struggling with fierce wind and torrential rain. However, westerners have no favorable impression on petrel. They usually associate it with catastrophes and disasters.

\section{The Same Animal Words with Both Similar and Different Associations}

Examples above demonstrate different associations of the same animal words in Chinese and English cultures. Searching many professional papers, the author finds that there are many contradictions on the same animal words, for example, many experts put "dog"(狗) in the category of "the same animal words with different associations in Chinese and English", however, besides differences, "dog" has the corresponding implication in both languages. Examples below show the same animal names with both relatively corresponding and different associations.

(1) "Dog": Dog has quite different values in both traditional cultures. Under more circumstances, Chinese people think a dog is horrible with a symbol of being filthy and dirty, such as “狗杂种”(son of bitch). However, English people pay more attention to dog's brilliance and loyalty. But, there are also derogatory meanings for "dog” in English culture, such as “that/this dirty dog”(那个狗东西); “They say the villain is going to the dogs”(他们说这个恶棍快完蛋了).

(2) "Bull": In history, Chinese Peasants from one generation to another generation depend on the cow or the bull to plough farmland, so Chinese people hold great affection for them. In a Chinese legend "The Cowboy and the Weaver", the bull and the cowboy relied on each other and helped with each other. The bull dedicated himself to his master. Therefore, bull and cow have the implication of dedication and diligence as well as serving for the masses.

However, in English culture, there are many shortcomings in cow or bull, such as "a bull in a china shop"(鲁莽闯祸 的人). Although there are different associations of cow and bull in both languages, there are relatively corresponding meanings, such as "bull market"(牛市) which refers to a generally rising stock market.

(3) "Cuckoo": Chinese people consider the cuckoo as the harbinger of spring. The first singing of cuckoo means spring comes. Chinese people cherish the singing of cuckoo and Chinese poets in ancient times often eulogize cuckoo's ability to herald spring with poems. But westerners show mixed attitudes toward cuckoo. When hearing its call before April 6, they regard the call as a taboo, but on April 28 an auspicious one. Besides, cuckoo is also the symbol of ruining other people's happiness, for example, "a cuckoo in the nest" (a person who usurp the parental love of others)

(4) "Fox": Chinese and English people connect the identical connotations to fox like being greedy and sly or cunning. For instance, he is a fox, as cunning as a fox(他很奸诈). However, people curse coquette as “fox"(狐狸精) and people who like flattering as “fox"(狐媚,hu mei) in china. Although people in English-speaking countries consider that fox is cunning, they also speak highly of its charming appearance and shrewd inherence. On some occasions, many westerners surname their family name as "Fox", which indicates their preference to fox.

(5) "Peacock": According to Webster's Third New International Dictionary of English Language, the figurative meaning of this word is "one making a proud or arrogant display of himself". Thus it can be seen that peacock has derogatory meanings in English culture. Similarly, in Chinese peacock is considered as an animal with strong vanity with the love of beauty, such as “孔雀炫羽” ( peacock displays its feather ). More often than not, peacock is the symbol of beauty and propitiousness in Chinese culture. People in Dai ethnic group located in Yunnan like to dance peacock dance to show their charm and express their aspirations for happiness. However, English culture emphasizes the word's connotation of "pride" instead of "beauty".

(6)"Fish": In English, fish can be used figuratively to describe a human. for example, "Not knowing a foreign language, he felt like a fish out of water among so many foreigners". Correspondingly, fish in Chinese culture is also compared to people, such as “鱼龙混杂”(good people and the evil mix up). Moreover, “鱼”(fish )and another Chinese character “余” are a pair of homophonic words. “余” means abundance. So fish is also used to express the meaning of being auspicious in Chinese.

\section{Different Animal Words with Identical Cultural Meanings}

This category refers to those Chinese and English animal idioms and relative phrases which share the similar meanings and differ in the adaption of animal words. There are loads of Chinese and English idioms and proverbs that can be classified into this category. Some examples are as follows.

(1)English idioms: A small bird wants but a small nest.

Chinese idioms: 燕雀无鸿鹄之志.(How can swallows and sparrows understand the ambitions of wild swans?)

(2) English idioms: Take not the musket to kill a butterfly

Chinese idioms: 杀鸡焉用牛刀.(How can one use an ox-slaughtering knife to kill chickens?)

(3) English idioms: Carrion crows bewail the dead sheep, and then eat them. 
Chinese idioms:猫哭老鼠假慈悲.(Cats bewail the mice and eat them).

(4) English idioms: A baited cat may grow as fierce as a lion.

Chinese idioms:狗急跳墙.(Desperation drives a dog to jump over wall)

(5) English idioms: The scalded cat fears cold water.

Chinese idioms:一朝被蛇 咬, 十年怕井绳.(Once bitten by a snake, one fears rope for the next ten years)

(6) English idioms: If you sell your cow, you sell her milk too.

Chinese idioms:杀鸡取卵.(Kill the hen for eggs)

(7) English idioms: Where the deer is slain, some of her blood will lie

Chinese idioms: 麻雀飞过留个影.(A sparrow makes a shadow when it flies by)

(8) English idioms: Love me, love my dog.

Chinese idioms: 爱屋及乌.(Love the house and the crow on it)

\section{E. Unique Cultural Connotations in One Language While Vacant in the Other Language.}

Just as mentioned above, different values drawn from the same object exist due to different cultures. It is not a rare thing that people in one country endow certain objects with cultural connotations which is void in another country. Meanwhile, the same animal word possesses remarkably abundant cultural connotations in one country, while in another country it lacks relatively associative meanings thus causinga phenomenon of vacancy in cultural connotations.

(1)"Buffalo": there is a phrase called "to buffalo" in English countries while there is no such usage in Chinese culture. The idiom initially meant "making somebody lose bearings or confused". Then it extended into "threatening others or frightening others". This idiom is connected with American history of western development. At that time, people in western America started to hunt buffalo to make a fortune, but they found hunting wasn't easy because buffalo was too strong to be conquered for them, so someone complained that we are "buffaloed". In Chinese culture, there are no relative implications of this animal.

(2) "Beaver": Beaver is a kind of industrious animal and it is famous for being good at constructing dams. It use branches, stone and ooze to build a dam which can intercept water into lair. So "eager beaver" describes hard-working people. It has also a derogatory meaning that someone endeavors to work excessively in order to ingratiate the superior. However, in Chinese culture, the associative meaning of this animal word is vacant.

(3) "Silkworm": Silkworm originated in China. Silk spits and weaves silk fabrics that are favored by people from home and abroad. The Silk Road has been prevailing for centuries. Chinese silkworm boasts a profound history with its spirit of dedication and has been engraved in Chinese people's heart. However, silkworm is just a kind of worm in English culture.

(4) "Tortoise and Crane": In China people think tortoise and crane have the implication of longevity. Crane is regarded as a bird that the immortal ride in Chinese culture, so it is also called immortal crane. When Chinese people celebrate the elderly's birthday, they often give a picture of crane as a present which symbolizes good health and longevity. And “鹤立鸡群” is a metaphor referring to those who are superior to others. However, there is no associative meaning in western countries. In English, "crane” only means "large bird with long legs, neck and beak." (Hornby, 1997, P.330) Therefore, they are often confused by delivering a picture of crane as a birthday gift in Chinese. Tortoise symbolizes longevity as well. There are always tortoises in the front of ancient architectures such as palaces and temples. In Chinese, the word “tortoise” also symbolizes cuckold: if a person is called “王八”(tortoise), it is extremely insulting, while the associative meanings of tortoise and crane are vacant in English.

\section{The Available Translation Strategies for Animal Phrases}

In dealing with the translation, two effective strategies-domestication and foreignization- are attracting scholars' attentions. Domestication and foreignization, two terminologies used by Lawrence Venuti in 1995, originated from the German thinker Schleiermacher's speech On the Different Methods of Translating in 1813. In Schleiermacher's perspective, "There are only two methods of translation, either the translation does not bother the original author and leads the reader to approach the author or the translator tries not to bother the reader and leads the original author to approach the reader"'(Schulte \& Biguenet, 1992,p.42).In this part, the author will use these two strategies to deal with the translation of animal-related phrases.

\section{A. Domestication}

Domestication is target culture-oriented. And it refers to the translation strategy in which a transparent style is applied so as to minimize the strangeness of the foreign text for target language readers.

Eugene A. Nida is one of the representatives of the translation theory of domestication. He puts forward the concept of "functional equivalence" and advocates that readers should be put in the priority in considering translating the cultural dissimilarities and discrepancies.(Nida, 1993, P.121) 
When the cultural meanings in the source text is unfamiliar to the target language readers, the translator will replace that cultural meanings with what is familiar to the target language readers thus achieving the same effect to the target language readers as to the source language readers.

Domestication is usually used in animals with different implications in both cultures or in animal words with unique meanings in one country but with void connotations in another country.

Here are some examples: the English idiom “to talk horse” is translated in “吹牛” instead of “吹马”; “a rat in the hole” is put into “瓮中之鳖” instead of “洞中之鳖”;“a dead lion” is translated into “纸老虎”instead of “一只死狒 子”;“to place oneself in the lion’s mouth” is translated into “置身虎口”, instead of “置于狮子ロ中”;“"a bull in a china shop” is translated into “爱闯祸的人” instead of “瓷器店里的一头公牛.”The chinese idiom “落汤鸡”is translated into “a drowned rat” instead of “a drowned hen”, “指鹿为马”is translated into “to talk black into white” instead of “to talk a deer into a horse."

When the translator makes efforts to transfer the source cultural elements into the target language, he is supposed to take into accounts the cultural connotations or associative differences of animal words and then make the source language culture close to the target language culture so as to avoid misunderstanding and conflicts.

\section{B. Foreignization}

Foreignization is source culture-oriented. And it designates the type of translation in which a target text "deliberately breaks target conventions by retaining something of the foreignness of the original" (Shuttleworth \& Cowie, 1997, P.59).

Lawrence Venuti is one of the representatives of the foreignization. He puts forward the concept of 'anti-translation' which aims at resisting target language domination and emphasizing cultural differences.

In general, foreignization is less commonly used unless the same animal word has an identical meaning in both countries just as the animal words mentioned before - the same animal words with identical meanings. Sometimes, an English proverb containing animal word has an equivalent saying in Chinese. In such case, it is better to use the translation strategy of foreignization to translate it from source language into target language. For example, "he is merely parroting what others have said”(他只是在鸭鹉学舌); “he is as gentle as a sheep” (他像小绵羊一样温顺); “he is as busy as bees"(他像蜜蜂一样忙碌).

\section{Domestication plus Notes and Foreignization plus Explanation}

The strategy of domestication and the strategy of foreignization are used complementarily in practical translation. On certain and necessary occasions, we should use foreignization or domestication plus explanations to translate animal related phrases to preserve original cultural connotations, avoiding the loss of original style and flavor.

1. Domestication plus Notes

It is hard to translate the Chinese-featured or English-featured idioms and phrases in respective masterpieces, mythologies, allegories or legends, the omission of them will make the target version dull and abrupt. In such a case, domestication plus notes can be used to explain the cultural background informations the reader do not have.

Here are two examples: “he is crying wolf”can be translated as “他在说假话”. In order to let the target readers know the origin of this idiom, the translator can add a Chinese note the main idea of which can be as follows: The original idiom is from Aesop's Fables. A young shepherd pastured sheep on the mountain and he cried falsely that wolves came for there times just for fun, and all villagers put their own farm work aside to help him, but they found there was no wolf. When wolves really came, the shepherd called for help desperately but every farmer turned their back on him because of his lying.

“He can be relied on, and he eats no fish”can be translated as “他为人可靠，他很忠诚”. To fulfil his duty fully, the translator should better add a Chinese note the content of which is like this: '“'to eat no fish' is an English allusion, it means that loyal Jesus Christians declined to obey the custom of only eating fish on Friday of Roman Catholic in the age of Queen Elizabeth, rather, they advocated and practised total prohibition of eating fish.”

2. Foreignization plus Explanation

In some cases, foreignization cannot fully convey the true meaning of the original, especially the implied meanings. In such cases, The translation strategy of foreignization plus notes seem to be quite necessary to make the translation easier to be understood. For example, shed crocodile's tear's is translated as “鳄鱼的眼泪假惺惺”. The last three characters acting as furthur explnantion clearly state the connaotative meaning of this animal phrase.

Other examples: the Chinese idiom “猫哭老鼠” is translated into “the cat crying over the mouse, merely a false pity”; the English idiom “To lead a cat-and-dog life” can be translatedas “过着猫和狗的生活,吵吵闹闹”. The bold-faced parts are necessary explanations

To an excellent translator, these four feasible translation strategies should be all took into consideration. When 
translating idioms or phrases with animal words, translators are supposed to use domestication, foreignization, domestication plus notes or foreignization plus notes if necessary.

\section{CONCLUSION}

This paper makes a comparative study of animal words in Chinese and English cultures. The comparative categories are as follows: the same animal words with identical meanings; the same animal words with different cultural meanings; the same animal names with both corresponding and different meanings; different animal relative phrases with identical cultural meanings and unique cultural connotations in one language while vacant in the other language. Animal words are the treasure of the language and culture for all countries, and they have their own characters or features with geographical, religious, literary, and psychological color. It is important and essential to have a comprehensive knowledge of animal words in cross-cultural communications.

When it comes to translation of animal relative phrases, the symbols of some animals coincide fully or partially in Chinese and English due to cultural similarity and particularity. The cultural gap can be narrowed by perfect translation so as to diminish the cross-cultural misunderstanding. This paper deals with translation of animal idioms and relative phrases with domestication, foreignization, and domestication or foreignization plus explanation so as to reach dynamic equivalence of source language and target language.

\section{REFERENCES}

[1] Dong, Shu. (2005). Cultural Disparity between English and Chinese Idioms and Their Translation in Journal of the Staff and Worker's University, (2): 102-103.

[2] Hornby, A S. (1997).Oxford Advanced Learner's English-Chinese Dictionary of Current English. Beijing: The Commercial Press.

[3] Liao, Guangrong. (2000).Comparison of English and Chinese Culture-loaded Animal Words in. Foreign Languages, (5): 17-26.

[4] Liu, Mingzhi. (2001). Comparison of Associative Meanings of Corresponding Chinese and English Animal words in Journal of Honghe University, (5):16-19.

[5] Ma, Yingjie. (1996). Cultural Marks of Animal Images: On the Cultural gaps of Animal Words in English and Chinese in Journal of Henan Normal University,(4) :49-50.

[6] Nida, Eugene A. (1993). Language, Culture, and Translating. Shanghai: Shanghai Foreign Language Education Press.

[7] Nida, Eugene A. \& Charles Taber. (1982). The Theory and Practice of Translation. Shanghai: Shanghai Foreign Language Education press.

[8] Schulte, R. et al. (1992).Theories of Translation: An Anthology of Essays from Dryden to Derrida. Chicago and London: The University of Chicago Press.

[9] Shuttlewoth, M. et al. (1997). Dictionary Translation Studies. Manchester, UK: St Jerome Publishing House.

[10] Wang, Dechun, et al. (1999). Similar National Customs in Terms of Animal Words in English and Chinese. Shanghai: Shanghai Foreign Language Education Press.

[11] Xiong, Yan. (2005). Domestication and Foreignization in Journal of HuBei Adult Education Institute, (1):62-64.

[12] Zhang, Ning. (1999). On the Cultural Disparity and Translation of English Idioms in Chinese Translators Journal, (3):23-25.

Fade Wang was born in Shandong, China in 1967. He receives his M.A. in English language and literature from Shandong University, China in 1995. He is currently an associate professor in Foreign Language College, Huaiyin Institute of Technology, Jiangsu, China. His research interests include bilingual translation between English and Chinese, English and American litera ture.

Minglan Zhang was born in Shandong, China in 1967. She received her M.A.in English literature from Guangxi Normal University, China in 2005. She is currently an associate professor in Foreign Language College, Huaiyin Institute of Technology, Jiangsu, China. Her research interests include English and American literature. 